\title{
Analisis Kandungan Mineral Daun Kelor (Moringa oleifera Lamk.) Menggunakan Spektrometer XRF (X-Ray Fluorescence)
}

\author{
Algafari B. Manggara*1 dan Muh. Shofi ${ }^{2}$ \\ ${ }^{1}$ Program Studi Kimia, Institut IImu Kesehatan Bhakti Wiyata Kediri, Jawa Timur, Indonesia \\ ${ }^{2}$ Program Studi Biologi, Institut IImu Kesehatan Bhakti Wiyata Kediri, Jawa Timur, Indonesia
}

*Email: algamanggara@gmail.com

\begin{abstract}
Abstrak
Daun kelor (Moringa oleifera Lamk.) banyak dimanfaatkan untuk bidang kesehatan, salah satunya adalah untuk memenuhi kebutuhan mineral dalam tubuh. Informasi yang tepat akan kandungan dan kadar mineral dalam daun kelor sangat diperlukan untuk mengetahui jumlah takaran konsumsi. Analisis mineral dalam daun kelor masih terbatas menggunakan alat AAS (Atomic Absorption Spectrometer) pada jenis mineral makro dan belum mengidentifikasi semua mineral yang ada. Analisis menggunakan alat spektrometer XRF (X-Ray Fluorescence) untuk bahan organik relatif belum banyak dilakukan dan memiliki keuntungan yaitu dapat menentukan hampir semua mineral yang ada dalam satu kali pengukuran. Atas dasar belum adanya informasi yang tepat akan komposisi dan kadar mineral daun kelor, serta kelebihan metode XRF maka dilakukan penelitian analisis kandungan mineral daun kelor menggunakan spektrometer XRF. Metode yang dilakukan pada penelitian ini dengan cara membuat daun kelor menjadi kering dan berbentuk serbuk. Selanjutnya sampel serbuk daun kelor dianalisis menggunakan alat spektrometer XRF. Hasil penelitian menunjukkan bahwa komposisi mineral dalam daun kelor adalah $\mathrm{P}, \mathrm{S}, \mathrm{K}, \mathrm{Ca}, \mathrm{Ti}, \mathrm{Cr}, \mathrm{Mn}, \mathrm{Fe}, \mathrm{Ni}, \mathrm{Cu}, \mathrm{Zn}$, Mo, Sr, Ba, dan Re dengan kadar berturut-turut adalah 12,84; 23,45; 264,96; 603,77; 1,05; 1,52; 2,68; 20,49; 22,$60 ; 7,59 ; 2,87 ; 11,69 ; 14,52 ; 10,04 ;$ dan $13,62 \mathrm{mg} / 100 \mathrm{~g}$. Hasil penentuan komposisi mineral dalam daun kelor ini, mungkin dapat digunakan untuk memformulasikan dalam material biologis suplemen mineral untuk memenuhi kebutuhan nutrisi tubuh.
\end{abstract}

Kata kunci: Daun kelor, XRF, Mineral.

\section{Pendahuluan}

Daun kelor memiliki nama latin Moringa oleifera Lamk. banyak dimanfaatkan untuk bidang kesehatan, antara lain untuk mengatasi masalah kekurangan gizi, kelaparan, serta menyembuhkan dan mencegah berbagai penyakit [7]. Pemanfaatan daun kelor masih terbatas, terutama beberapa daerah di Indonesia yang masih memiliki adat istiadat yang kuat. Di beberapa daerah tersebut daun kelor lebih banyak dimanfaatkan untuk memandikan jenazah, meluruhkan jimat, dan sebagai makanan ternak.

Salah satu manfaat daun kelor yang sedikit terabaikan adalah kandungan 
mineralnya. Melalui konsumsi daun kelor dalam menu makanan dapat digunakan untuk memenuhi kebutuhan mineral dalam tubuh. Informasi yang tepat akan kandungan dan kadar mineral dalam daun kelor sangat diperlukan untuk mengetahui jumlah takaran konsumsi harian. Beberapa penelitian telah dilakukan untuk mengetahui kadar mineral dalam daun kelor, tetapi masih terbatas pada jenis mineral makro dan belum mengidentifikasi semua mineral yang ada. Analisis kandungan mineral makro secara kuantitatif dalam material biologis umumnya menggunakan alat titrasi, spektrofotometer UV-Vis, dan AAS (Atomic Absorption Spectrometer) $[9,16]$. Alat-alat tersebut memiliki beberapa kelemahan antara lain: diperlukan larutan standar, menganalisis hanya untuk satu jenis mineral, preparasi sampel yang bersifat destruktif, jumlah sampel yang dibutuhkan relatif besar, dan analisisnya tidak secara langsung karena memerlukan perhitungan untuk menentukan kadarnya.

Analisis menggunakan alat spektrometer XRF (X-Ray Fluorescence) memiliki beberapa keuntungan, sampel yang diperlukan relatif kecil (sekitar 1 gram), menganalisis tanpa adanya standar, memiliki akurasi dan ketelitian yang tinggi, serta dapat menentukan hampir semua kandungan mineral dalam material biologis yang secara langsung dapat diketahui hasilnya [13]. Atas dasar belum adanya informasi yang tepat akan komposisi dan kadar mineral daun kelor, serta kelebihan metode XRF maka dilakukan penelitian analisis kandungan mineral daun kelor menggunakan spektrometer XRF.

\section{Percobaan}

\subsection{Alat dan Bahan}

Alat-alat yang digunakan dalam penelitian ini adalah Spektrometer X-Ray Fluorescence (XRF) Minipal 4 (EDXRF) merek Philips, tanur, oven, neraca analitik, ayakan ukuran 100 mesh, mortar, stampler, cawan porselen, krusibel porselen, dan gelas kimia. Sedangkan bahan yang digunakan dalam penelitian ini adalah $\mathrm{HNO}_{3}$ (SigmaAldrich), akuades, dan sampel daun kelor yang diambil dari daerah Tulungagung, Jawa Timur.

\subsection{Metode Penelitian}

Sejumlah 100 gram sampel daun kelor segar dicuci dengan akuades kemudian dikeringkan di oven pada suhu $70{ }^{\circ} \mathrm{C}$ selama 48 jam. Sampel daun kelor yang telah kering selanjutnya digerus dan diayak dengan dengan ayakan ukuran 100 mesh. Semua sampel serbuk daun kelor ditaruh dalam krusibel porselen kemudian diabukan pada suhu $500{ }^{\circ} \mathrm{C}$ selama 2 jam dan dibiarkan dingin. Setelah dingin ditambahkan asam nitrat yang selanjutnya dipanaskan pada suhu $120{ }^{\circ} \mathrm{C}$ hingga terbentuk serbuk abu daun kelor kembali dan ditimbang beratnya. ${ }^{13}$ Sampel serbuk abu daun kelor selanjutnya dibuat pelet dengan ukuran diameter $3 \mathrm{~cm}$ dan tebal $0,10 \mathrm{~cm}$ dengan menggunakan 
mesin pelet bertekanan hidrolik 10 ton $/ \mathrm{cm}^{2}$. Sampel pelet daun kelor siap untuk dilakukan uji XRF $[1,2,4]$.

\subsection{Analysis}

Sampel serbuk abu daun kelor yang berbentuk pelet selanjutnya di ukur menggunakan alat Spektrometer XRF. Sampel pelet diletakkan di chamber XRF, diukur pada 8 dan $12 \mathrm{KV}$ dengan intensitas 0,32-0,34 mA. Hasil dari analisis berupa print out data komposisi dan kadar mineral dalam daun kelor.

\section{Hasil dan Pembahasan}

Sampel daun kelor yang dianalisis dalam penelitian ini terlebih dahulu dilakukan pengovenan untuk menghilangkan kadar air dan dibuat serbuk untuk memudahkan dalam proses analisis selanjutnya. Sampel daun kelor diabukan dengan cara pemanasan pada suhu $500{ }^{\circ} \mathrm{C}$ untuk menguraikan senyawa-senyawa organik yang ditandai dengan terbentuknya abu berwarna putih. Abu berwarna putih tersebut diduga merupakan mineral yang sebelumnya mengisi rongga sel daun kelor. Umumnya mineral tersebut berupa campuran mineral bebas (natrium, kalium, kalsium, magnesium, mangan, besi, silika, dan aluminium) maupun senyawa anorganik (karbonat, fosfat, silikat, sulfat, dan klorida) $[5$, 10]. Penambahan asam nitrat dan pengovenan kembali pada suhu $120{ }^{\circ} \mathrm{C}$ bertujuan untuk mengoksidasi senyawa organik dan senyawa lain yang masih terdapat dalam sampel sehingga diharapkan yang tersisa adalah senyawa-senyawa anorganik (mineral) yang telah diketahui beratnya dengan melakukan proses penimbangan kembali. Hasil proses ini diasumsikan bahwa yang zat yang tersisa dalam serbuk sampel daun kelor adalah mineral-mineral yang akan ditentukan jenis dan kadarnya.

Hasil analisis XRF menunjukkan persentase $(\%)$ kandungan unsur-unsur yang terdapat dalam sampel daun kelor. Persentase hasil tersebut merupakan perhitungan relatif terhadap keseluruhan luas peak yang muncul pada pola serapan, artinya luas puncak tertentu untuk unsur tertentu dibandingkan dengan keseluruhan luas puncak yang muncul. Jadi data yang dihasilkan merupakan jumlah mol dari masing-masing unsur dalam sampel daun kelor. Selanjutnya data tersebut dikonversi menjadi persen massa dengan cara mengkalikan dengan massa atom relatif masing-masing unsur yang muncul. Hasil persentase massa masing-masing unsur dikalikan dengan berat sampel daun kelor yang telah melalui proses destruksi (penghilangan senyawa organik) atau sampel mineral daun kelor sehingga diketahui berat dari masing-masing unsur. Berat masingmasing unsur tersebut merupakan berat masing-masing mineral per 100 gram berat sampel daun kelor segar. Hasil analisis akhir jenis dan kadar mineral dalam daun kelor ditunjukkan pada Tabel 1. 
Tabel 1. Jenis dan Kadar Mineral dalam Daun Kelor

\begin{tabular}{|c|l|c|}
\hline No & \multicolumn{1}{|c|}{ Mineral } & $\begin{array}{c}\text { Kadar } \\
\text { (mg/100 g) }\end{array}$ \\
\hline 1 & $\mathrm{P}$ (Fosfor) & 12,84 \\
\hline 2 & $\mathrm{~S}$ (Belerang) & 23,45 \\
\hline 3 & $\mathrm{~K}$ (kalium) & 264,96 \\
\hline 4 & $\mathrm{Ca}$ (kalsium) & 603,77 \\
\hline 5 & $\mathrm{Ti}$ (Titanium) & 1,05 \\
\hline 6 & $\mathrm{Cr}$ (Kromium) & 1,52 \\
\hline 7 & $\mathrm{Mn}$ (Mangan) & 2,68 \\
\hline 8 & $\mathrm{Fe}$ (Besi) & 20,49 \\
\hline 9 & $\mathrm{Ni}$ (Nikel) & 22,60 \\
\hline 10 & $\mathrm{Cu}$ (Tembaga) & 7,59 \\
\hline 11 & $\mathrm{Zn}$ (Seng) & 2,87 \\
\hline 12 & $\mathrm{Mo}$ (Molibdenum) & 11,69 \\
\hline 13 & $\mathrm{Sr}$ (Stronsium) & 14,52 \\
\hline 14 & Ba (Barium) & 10,04 \\
\hline 15 & $\mathrm{Re}$ (Renium) & 13,62 \\
\hline & & \\
\hline
\end{tabular}

Berdasarkan Tabel 1 diketahui bahwa dalam daun kelor ditemukan 15 jenis mineral yang terdiri dari mineral makro dan mikro. Mineral makro yang teridentifikasi yaitu kalsium, kalium, fosfor, dan belerang. Mineral makro merupakan mineral yang diperlukan tubuh dalam jumlah besar. Mineral tertinggi yang ditemukan dalam daun kelor adalah kalsium dengan kadar $603,77 \mathrm{mg} / 100$ g. Kalsium adalah mineral makro yang penting dalam pertumbuhan tulang dan gigi, membantu proses pembekuan darah, aktivator saraf dan otak, aktivator enzim, aktivator otot jantung, melindungi tubuh terhadap absorpsi zat radioaktif [6, 9]. Menurut National Health Service (NHS) kebutuhan mineral kalsium untuk tubuh sekitar 700 sampai $800 \mathrm{mg}$ per hari. Kadar kalsium yang tinggi pada kelor berpotensi untuk memenuhi kebutuhan kalsium tubuh, dimana umumnya kebutuhan kalsium tubuh dipenuhi dari susu. Kadar kalsium dalam susu adalah $125 \mathrm{mg} / 100 \mathrm{~g}$. Hal ini menunjukkan bahwa kalsium dalam kelor lebih tinggi sekitar 5 kali lipat dari kalsium susu.

Kalium berada di urutuan kedua mineral makro dalam daun kelor dengan kadar $264,96 \mathrm{mg} / 100$ g. Kalium dalam tubuh berperan dalam mengatur detak jantung, memelihara keseimbangan air, transmisi saraf, memelihara keseimbangan asam basa, katalisator, mengatur kontraksi otot, mengatur sekresi insulin dari pankreas, dan memelihara permeabilitas membran sel $[6,9$, 22]. Kebutuhan mineral kalium dalam tubuh menurut NHS adalah sekitar $2000 \mathrm{mg}$ per hari. Kadar kalium yang cukup tinggi pada kelor berpotensi untuk memenuhi kebutuhan kalium tubuh.

Dua mineral makro berikutnya dalam daun kelor adalah fosfor dengan kadar 12,84 $\mathrm{mg} / 100 \mathrm{~g}$ dan belerang dengan kadar 23,45 $\mathrm{mg} / 100 \mathrm{~g}$ ). Menurut NHS kebutuhan mineral fosfor dalam tubuh sekitar $550 \mathrm{mg}$ per hari dan untuk belerang belum ada rekomendasi untuk pemenuhannya karena dapat tercukupi dari pola makan yang sehat. Peranan fosfor dalam tubuh adalah membantu dalam proses 
pembentukan tulang dan gigi, proses metabolisme, kontraksi otot, aktivitas saraf, membentuk fosfatid (bagian dari plasma darah), menjaga keseimbangan asam basa, pengaturan aktivitas hormon, dan efektivitas beberapa vitamin. Sementara belerang berperan sebagai aktivator enzim, penyimpanan dan pembebasan energi, komponen vitamin (thiamin, biotin, dan asam pantotenat), dan komponen dalam proses detoksikasi [6, 9]. Keberadaan mineral fosfor dan belerang dalam daun kelor masih dapat dipakai sebagai alternatif untuk mengatasi kekurangan fosfor dan belerang dalam tubuh meskipun kadarnya relatif rendah.

Mineral mikro yang teridentifikasi dalam daun kelor yaitu besi, kromium, mangan, molibdenum, seng, tembaga, dan nikel. Mineral besi dalam daun kelor menduduki urutan tertinggi kedua dari mineral mikro yang ditemukan dalam daun kelor dengan kadar 20,49 mg/100 g. Kebutuhan mineral besi untuk tubuh menurut NHS adalah sekitar 8 sampai $18 \mathrm{mg}$ per hari. Mineral besi dalam tubuh berfungsi untuk pembentukan hemoglobin (pencegahan terhadap anemia), sistem kekebalan tubuh, komponen enzim sitokrom (enzim dalam respirasi), dan berperan dalam peningkatan kecerdasan [6, 9]. Kadar besi yang cukup tinggi pada daun kelor sangat berpotensi untuk memenuhi kebutuhan besi dalam tubuh.
Mineral mikro berikutnya yang teridentifikasi dalam daun kelor adalah seng dengan kadar 2,87 mg/100 g. Kebutuhan mineral seng untuk tubuh menurut NHS adalah sekitar $12 \mathrm{mg}$ per hari. Mineral seng dalam tubuh berfungsi membantu dalam proses penyembuhan luka dan kesehatan kulit, metabolisme karbohidrat, protein, dan lemak, pertumbuhan dan reproduksi, kepekaan terhadap rasa dan bau, proses kekebalan tubuh, memelihara kesehatan mata, menghambat virus, dan mengurangi risiko kanker [6, 9]. Meskipun kadar seng pada daun kelor relatif sedikit, masih dapat dipakai sebagai alternatif untuk mengatasi kekurangan seng dalam tubuh.

Tembaga adalah mineral mikro berikutnya yang ditemukan dalam daun kelor dengan kadar 7,59 mg/100 g. Kebutuhan mineral tembaga untuk tubuh menurut NHS adalah sekitar 1,2 mg per hari. Mineral tembaga dalam tubuh berfungsi dalam pembentukan eritrosit dan hemoglobin, komponen enzim dan protein, aktivator saraf, dan pembentukan hormon $[11,21]$. Kadar tembaga pada daun kelor yang relatif tinggi, berpotensi untuk memenuhi kebutuhan tembaga dalam tubuh.

Mineral mikro kromium ditemukan dalam daun kelor relatif sedikit dengan kadar $1,52 \mathrm{mg} / 100$ g. Kebutuhan mineral kromium untuk tubuh menurut NHS adalah sekitar 25 mg per hari. Mineral kromium dalam tubuh berfungsi dalam metabolisme karbohidrat dan lemak, bersama-sama dengan insulin 
memudahkan masuknya glukosa ke dalam sel [11, 21]. Meskipun kadar kromium pada daun kelor relatif sedikit, dapat sebagai alternatif untuk mengatasi kekurangan kromium dalam tubuh.

Mineral mikro yang juga ditemukan dalam jumlah yang relatif sedikit adalah mangan dengan kadar 2,68 mg/100 g. Kebutuhan mineral mangan untuk tubuh menurut NHS adalah sekitar $5 \mathrm{mg}$ per hari. Mineral mangan dalam tubuh berfungsi sebagai kofaktor berbagai enzim seperti sintesis ureum, pembentukan jaringan ikat dan tulang, mencegah peroksidasi lemak oleh radikal bebas, pengontrolan gula darah, metabolisme energi, fungsi hormon tiroid, fungsi otak, dan untuk pengontrolan neurotransmitter [11, 21]. Kadar mineral mangan pada daun kelor relatif sedikit, tetapi masih dapat digunakan untuk mengatasi kekurangan kromium yang kebutuhannya dalan tubuh tidak terlalu tinggi.

Molibdenum ditemukan dalam daun kelor dengan kadar $11,69 \mathrm{mg} / 100 \mathrm{~g}$. Kebutuhan mineral molibdenum untuk tubuh menurut NHS adalah sekitar 20 sampai 50 mg per hari. Mineral molibdenum dalam tubuh berfungsi sebagai kofaktor berbagai enzim, mengkatalis reaksi oksidasi-reduksi, penawar racun alkohol, metabolisme sulfur, dan mencegah anemia $[11,21]$. Meskipun kadar molibdenum pada daun kelor relatif sedikit, masih dapat dipakai sebagai alternatif untuk memenuhi kebutuhan molibdenum dalam tubuh.
Mineral mikro tertinggi yang teridentifikasi adalah nikel dengan kadar $22,60 \mathrm{mg} / 100$ g. Kebutuhan mineral nikel untuk tubuh menurut NHS adalah sekitar 10 mg per hari. Mineral nikel dalam tubuh berfungsi dalam proses hematopoiesis dan merupakan bagian dari sel darah merah, proses pemulihan tubuh, membantu proses penyerapan vitamin B12 dan vitamin C, membantu proses penyusunan kalsium dalam tubuh [11, 21]. Kadar nikel pada daun kelor yang relatif tinggi, berpotensi untuk memenuhi kebutuhan nikel dalam tubuh.

Mineral mikro lainnya yang berhasil teridentifikasi adalah barium, stronsium, renium, titanium dengan kadar masingmasing berurutan 10,$04 ; 14,52 ; 13,62$; dan $1,05 \mathrm{mg} / 100 \mathrm{~g}$. Mineral-mineral tersebut ditemukan dalan jumlah yang relatif sedikit.

\section{Kesimpulan}

Hasil penelitian menunjukkan bahwa komposisi mineral dalam daun kelor ditemukan 15 jenis mineral yang terdiri dari mineral makro dan mikro yaitu $\mathrm{P}, \mathrm{S}, \mathrm{K}, \mathrm{Ca}$, Ti, Cr, Mn, Fe, Ni, Cu, Zn, Mo, Sr, Ba, dan Re dengan kadar berturut-turut adalah 12,84; 23,$45 ; 264,96 ; 603,77 ; 1,05 ; 1,52 ; 2,68$; 20,49; 22,60; 7,59; 2,87; 11,69; 14,52; 10,04; dan 13,62 mg/100g. Diketahui bahwa mineral yang memiliki kadar paling tinggi dibandingan mineral yang lain dalam daun kelor adalah kalsium dan kalium. Hasil analisis jenis dan kadar mineral dalam daun kelor ini, berpotensi untuk memformulasikan 
suplemen mineral dalam memenuhi kebutuhan nutrisi tubuh.

\section{Ucapan Terima Kasih}

Ucapan terima kasih diberikan pada Kementrian Ristekdikti yang telah memberikan Hibah Penelitian Tahun Anggaran 2017 melalui skema Penelitian Dosen Pemula dengan nomor kontrak 078/SP2H/K2/KM/2017.

\section{Daftar Pustaka}

[1] B. H. Sasangka, J. Mellawati, T. Tjiptosumirat, dan Suharyono 'Analisis Kandungan Mineral Dalam Hijauan Pakan Ternak Dengan Menggunakan, Spektrometri Pendar', Pusat Aplikasi Penelitian dan Pengembangan Aplikasi Isotop dan Radiasi, 1998, 137-40.

[2] Firsoni, Y. Menry, dan B. H. Sasangka, 'Studi Kandungan Unsur Mikro Pada UMMB Sebagai Suplemen Pakan Terna Ruminansia', Risalah Pertemuan Ilmiah Penelitian dan Pengembangan Aplikasi Isotop dan Radiasi, 2001.

[3] M. Aslam, F. Anwar, R. Nadeem, U. Rashid, T. G. Kazi, M. Nadeem, 'Mineral Composition of Moringa Oleifera Leaves and Pods From Different Regions of Punjab Pakistan', Asian Journal of Plant Sciences, 2005, 417-21.

[4] A. Saat, Z. Hamzah, and Z. A. Bakar, 'XRF Determination of Major Elemental Contents of Clay Samples from North-West Peninsular Malaysia', Journal of Nuclear and Related Technologies, 6.1, 2009, 230-36.

[5] Sukirno, S. Murniasih, 'Analisis Unsur Fe, $\mathrm{Ca}, \mathrm{Ti}, \mathrm{Ba}, \mathrm{Ce}, \mathrm{Zr}$ dan La Dalam Sedimen Laut Di Semenanjung Muria Dengan Metode
XRF', Ganendra, XII.1, Januari, 2009, 2531.

[6] S. S. Magat, M. C. Raquepo, and C. D. Pabustan, 'Mineral Macro-Nutrients, MicroNutrients and Other Elements in Leaves of Malunggay Plant (Moringa Oleifera) Sampled in Some Locations in The Phlilippines', Technology-Advisory Notes, September 2009.

[7] C. W. Yaméogo, M. D. Bengaly, A. Savadogo, 'Determination of Chemical Compostion and Nutritional Values of Moringa Oleifera', Pakistan Journal of Nutrition, 2011, 264-68.

[8] N. Santhiarsa, A. A. Sonief, E. Marsyahyo, Pratikto, 'Analisis Kualitatif Dan Kuantitatif Kandungan Unsur Logam Pada Serat Ijuk (Arenga Pinnata Fiber) dengan Pengujian XRF, AAS, LIBS', SNTTM XI, Oktober 2012.

[9] N. L. C. Fitriani, D. K. Walanda, dan N. Rahman, 'Penentuan Kadar Kalium (K) Dan Kalsium (Ca) Dalam Labu Siam (Sechium Edule) Serta Pengaruh Tempat Tumbuhnya', Jurnal Akademika Kimia, 1. November 2012, pp. 174-80.

[10] S. Yagi, A. E. A. Rahman, G. O. M. Elhassan and A. M. A. Mohammed, 'Elemental Analysis of Ten Sudanese Medicinal Plants Using X-Ray Fluorescence', Journal of Applied and Industrial Sciences, 1.1, April 2013, pp. 49-53.

[11] P. M. Aja, U. A. Ibiam, A. J. Uraku, O. U. Orji, C. E. Offor and B.U. Nwali, 'Comparative Proximate and Mineral Composition of Moringa Oleifera Leaf and Seed', Global Advanced Research Journal of Agricultural Science, Vol. 2.5 May 2013, pp. 137-41. 
[12] O.A Fakankun, J. O. Babayemi and J. J Utiaruk, 'Variations in the Mineral Composition and Heavy Metals Content of Moringa Oleifera', African Journal of Environmental Science and Technology, 7.6, Juni 2013, 372-79.

[13] T. Tezotto, J. L. Favarin, A. P. Neto, P. L. Gratao, R. A. Azevedo, P. Mazzafera, 'Simple Procedure for Nutrient Analysis of Coffee Plant with Energy Dispersive X-Ray Fluorescence Spectrometry (EDXRF) Scientia Agrícola, 70, July/ August 2013, 263-67.

[14] Z. Noor, S. B. Sumitro, M. Hidayat, A. H. Rahim, 'Karakteristik Atom Mineral Pada Osteoporosis Dengan Arsitektur Porosis Dan Nonporosis',MKB 45.1, 2013, 23-27.

[15] D. J. Patty, 'Penentuan Unsur Dalam Rambut Berdasarkan Karakteristik Pola Flouresensi Sinar X (XRF)', Prosiding FMIPA Universitas Pattimura, 2013, 219-25.

[16] L. Sakka, 'Analisa Kandungan Logam Kalsium Buah Pare (Momordica charantia L.) dengan Menggunakan Metode Spektrofotometri Serapan Atom', vol. 3, Nomor 6, 2013

[17] W. J. Asante, I. L. Nasare, D. T. Dery, K. O. Boadu and K. B. Kentil, 'Nutrient Composition of Moringa Oleifera Leaves from Two Agro Ecological Zones in Ghana', African Journal of Plant Science, 8.1, January 2014, 65-71.

[18] M. D. Adeoye, A. T. Lawal, L. A. Azeez and O. A. Olayiwola, 'Effect of solvent type on the yields and mineral compositions of the leaf extracts of Moringa oleifera L.' African Journal of Pure and Applied Chemistry. Vol 8(9), September 2014, pp. 134-146.

[19] S. A. Al Ameri, F. Y. Al Shaibani, A. J. Cheruth, A. I Al Awad, M. A. S. Al-Yafei, K. Karthishwaran, S. S. Kurup, 'Comparative Phytochemical Analysis of Moringa Oleifera', PharmacologyOnline, 3, December 2014, 216-221.

[20] M. O. Bello, K. Asubonteng, A. Sodamade, S. Adeniyi, 'Nutrient Potentials of Two Lesser Known Leafy Vegetables (Vitex Doniana L. and Sesamum Indicum L.)', International Food Research Journal, 21.5 2014, 1993-99.

[21] N. O. Nweze, and F. I. Nwafor, 'Phytochemical, Proximate and Mineral Composition of Leaf Extracts of Moringa Oleifera Lam. from Nsukka, South-Eastern Nigeria', IOSR Journal of Pharmacy and Biological Sciences, 9.1, 2014, 2319-7676.

[22] A Rochmawati, D. H. Effendi, dan S. Hamdani, 'Pengembangan Metode Analisis Kadar Kalium Dalam Daun Kelor (Moringa Oleifera) Dengan Metode Konduktometri', Prosiding Penelitian SPeSIA Unisba, 2015, 591-95. 